Author version: Ecotoxicology, vol.19(4); 2010; 604-613

\title{
Arsenite Tolerance and Biotransformation Potential in Estuarine Bacteria
}

\author{
Geeta S. Nagvenkar and N. Ramaiah* \\ National Institute of Oceanography \\ Council of Scientific and Industrial Research (CSIR) \\ Dona Paula, Goa 403004
}

\section{Abstract:}

Bacterial isolates from water and sediment samples from freshwater, estuarine and marine regions were tested for their growth in the presence of different concentrations of arsenic. Despite the generation times being longer in case of all bacterial isolates tested in nutrient broth with 200ppm Arsenite $\left(\mathrm{As}^{3+}\right)$, many of them were able to attain log phase and substantial growth variously between 36 and 96 hours. The isolates tolerating $\geq 200 \mathrm{ppm}$ arsenic (As) were found to belong to Enterobacteriaceae, Pseudomonas, Corynebaterium, Xanthomonas, Acinetobacter, Flavimonas and Micrococcus. Some of these environmental strains tolerant to $1000 \mathrm{ppm}$ arsenic were tested to realize their potential to detoxify arsenic. The rate of As biotransformation was faster by many of these strains. The percent of arsenite biotransformed/removed from the growth medium was the highest by a strain of Enterobacteriaceae (as much as $92 \%$ of the As in the growth medium by 120hrs) followed by that of Corynebaterium and Acinetobacter strains. From these observations it is clear that many environmental strains are capable of quite rapid biotransformation of As. Contamination of drinking water by toxic metalloid arsenic affects thousands of people worldwide. Many environmental isolates of bacteria which detoxify this metalloid would serve beneficial in the depuration processes. We suggest that only such strains capable of high tolerance to toxic arsenite, would biotransform As in polluted estuarine environments and would prove useful in As bioremediation applications.

*corresponding author; tel: +91 832 2450515; fax: +91 8322450602

email: ramaiah@nio.org

Key words: Arsenic tolerant bacteria, toxic metalloid, estuarine, As biotransformation, Arsenite, Enterobacteriaceae, Coynebacterium sp 


\section{Introduction:}

Arsenic (As), a toxic metalloid, is not quantitatively abundant but widely distributed. Natural input of As is from bedrock leaching, volcanoes and erosion from mineral deposits (Lee et al. 2005). In addition, As and its compounds enter aquatic bodies from mining activities, by washing from soils and atmosphere, effluents from metals and chemical production (Pacyna and Pacyna 2001), through the use of pesticides, herbicides, fungicides, rodenticides, insecticides, burning oil, coal, gasoline and wood (Nair et al. 2003). Its contamination of drinking water affects thousands of people worldwide (Nickson et al. 1998).

Arsenic is most damaging in its inorganic forms. As Williams and Silver (1984) and Neff (1997) suggest, due to greater cellular uptake, the trivalent arsenic [Arsenite $\left.\left(\mathrm{As}^{+3}\right)\right]$ is several times more toxic than pentavalent arsenic [Arsenate $\left(\mathrm{As}^{+5}\right)$ ]. Many studies have reported As concentrations in biota, sediment and water to be far above the levels tolerated by humans (Nickson et al. 1998). Observations on occurrence and distribution of native bacterial flora capable of metal tolerance are of relevance in microbial ecology to understand the extent of metal pollution and to realize the potential of such flora in detoxifying toxic substances. A toxic metal may be converted to a less toxic or, non- toxic entity by enzymatic oxidation or reduction (Erhlich 1997).

Arsenic is toxic to microorganisms, but certain bacteria and phytoplankton survive its exposure and, transform its species through oxidation, reduction and methylation (Osborne and Ehrlich 1976; Sanders and Windom 1980; Anderson and Bruland 1991). Many bacteria are known for their ability to transform inorganic species by oxidation or reduction (Weeger et al. 1999; Macy et al. 2000; Oremland and Stolz 2003). Some bacteria metabolize arsenic in a way that transforms water-soluble arsenite into the safer, insoluble arsenate (Weeger et al. 1999; Oremland et al. 2004), suggesting it might someday be possible to use the bacteria to clean up or reduce arsenic contamination of aquifers. Such transformations occur incidentally or, through specific detoxification mechanisms (Mukhopadhyay et al. 2002; Rosen 2002; Oremland and Stolz 2003; De et al. 2006). Microbial parameters are useful in monitoring environmental pollution by metals. Soil acts as a principal As sink, which accrues from the contaminated groundwater aquifers (Woolson et al. 1973). An index of As metabolizing bacteria at a given sampling site in the natural environment may be provided by determining the total number of arsenic tolerant bacteria. Such efforts will also help realize the potential of metal-tolerant bacteria to detoxify some of the toxic substances. 
Environmental studies on arsenic-resistant microflora have mostly focused on freshwater ecosystems. Attention to estuaries and adjacent coastal waters that are major repositories for natural and river-borne/watershed-derived As species is scanty. There is a need to increase our knowledge and understanding concerning the biogeochemical cycling of As and the impact of anthropogenically related inputs in the biologically more productive near shore regions. The uptake of metals and its compounds by marine organisms including bacteria leads to their modification and, in altered chemical forms, these compounds can move up the food chain (Chen et al. 2009; Liu et al. 2009), be bio-magnified, and reach human beings where they can result in chronic and/or acute ailments (Maher and Barwick 2003).

In the present study we quantified the percent of general estuarine bacterial flora capable of growing in nutrient medium containing 15, 25 and 50ppm $\mathrm{As}^{3+}$. Many isolates growing at 50ppm were exposed to higher As concentrations of up to $1000 \mathrm{ppm}$ to evaluate the tolerance of native bacterial flora to such concentrations of As. A few of them capable of tolerating 1000 ppm As were examined for their potential to biotransform/detoxify it in nutrient media amended with As at $200 \mathrm{ppm}$ arsenite.

\section{Materials and Methods:}

Sampling locations: Before joining the Arabian Sea off Marmugao, the rivers Zuari and Mandovi in the west coast of India flow through iron and manganese mining areas. Over 300 barges move iron-ore daily into the harbor from mining sites upstream of both the rivers for loading $\sim 15-20$ ore carriers for export (Nair et al. 2003). The region receives barge-related wastes in addition to the sizable domestic effluents (Sawkar et al. 2003). The As concentrations are reported to be in the range of $0.11-0.78 \mathrm{ppb}$ in water and, 5.84 - 9.72 in Mandovi and 5.07 - 10.20 ppb in Zuari sediment samples (Nair et al. 2003).

Sampling: Water and sediment samples were collected during pre-monsoon (May 2005), monsoon (September 2006) and post-monsoon (November 2005) seasons from the oligohaline 'freshwater', estuarine $(\sim 10-25 \mathrm{psu})$ zones in the lower stretches of River Mandovi and from an adjacent marine location (Fig 1). During pre monsoon [March-May] and post-monsoon, the salinity ranges [OctoberFebruary] between $<5$ (low tide times) and 15 (high tide duration) psu at the 'freshwater' location in the lower stretches of this river. It respectively ranges between $\sim 18$ and $\sim 30$ psu at the estuarine location. Both of these locations often experience salinities $<3$ psu during the monsoon [June- September] months. All samples were collected with precautions required for microbiological analysis, held on ice in an icebox and, transported to the laboratory for all following analyses, within 3-4 hrs of collection. 
Total viable counts (TVC): For enumerating TVC, samples from freshwater zones were spread plated onto nutrient agar (NA with composition $1^{-1}$ : peptic digest of animal tissue $5.0 \mathrm{~g}$, sodium chloride $5.0 \mathrm{~g}$, beef extract $1.5 \mathrm{~g}$, yeast extract $1.5 \mathrm{~g}$, agar $15 \mathrm{~g}$, distilled water $1000 \mathrm{ml}, \mathrm{p}^{\mathrm{H}} 7.4 \pm 0.2$ ). For enumerating TVC from estuarine and marine water samples, the nutrient agar medium with above composition was prepared respectively with $25 \%$ and $50 \%$ aged seawater. TVC from sediment samples from each zone were enumerated by plating 0.1 to $0.3 \mathrm{ml}$ aliquots in triplicates from $10^{2}$ and $10^{3}$ dilutions of each sample on NA plates with (for samples from estuarine and marine zones) or, without (for samples from freshwater zones) added seawater.

Enumeration and isolation of arsenic resistant bacteria (ARB): To enumerate and differentiate the natural flora capable of tolerating and, growing in media with As, nutrient agar (NA) was amended with arsenic trioxide $\left(\mathrm{As}_{2} \mathrm{O}_{3}\right)$. Aliquots of 0.1 and $0.2 \mathrm{ml}$ water samples were spread plated in triplicate onto NA amended with $15(\equiv 75 \mu \mathrm{M}), 25$ and $50 \mathrm{ppm}$ As from $\mathrm{As}_{2} \mathrm{O}_{3}$. Sediment samples were suitably diluted to attain 100 or 1000 fold dilutions and replicate aliquots of $0.1 \mathrm{ml}$ supernatants from each dilution were similarly spread plated. All plates were incubated at room temperature $\left(27 \pm 2.5^{\circ} \mathrm{C}\right)$ up to $48 \mathrm{hrs}$ and final counts of colonies were noted. Dry weights of sediment samples were determined and colony counts expressed on dry weight basis.

Many isolates from the NA plates with $50 \mathrm{ppm}$ As were picked out, purified and grown on 100, 200, 300 and $1000 \mathrm{ppm}$ for obtaining bacterial strains tolerating the highest As concentration. All isolates that grew on NA with 1000ppm As were designated as As resistant bacteria (ARB) and used for further studies

Identification of ARB: The ARB were purified and maintained on nutrient agar slants containing $1000 \mathrm{ppm}$ As. Morphological and biochemical characteristics were examined for identifying these isolates according to Holt et al. (2000).

Growth characteristics of ARB: The growth of nine ARB isolates was examined by inoculating them in the nutrient broth $\left(\mathrm{NB}\right.$, containing $\left[\mathrm{L}^{-1}\right] 5.0 \mathrm{~g}$ peptone; $3.0 \mathrm{~g}$ yeast extract and $1000 \mathrm{ml}$ distilled water for freshwater samples) amended with 200ppm As. The NB with $25 \%$ aged seawater was used for examining the growth of estuarine isolates. The ARB were also inoculated into NB without As and examined for growth. All the culture-flasks were incubated on a shaker (at $150 \mathrm{rpm}$ ) at room temperature $\left(26 \pm 2{ }^{\circ} \mathrm{C}\right)$ and OD660 measured every $3 \mathrm{hr}$ for over 5 days. To circumvent wide variation in the inoculum size of cell numbers for monitoring growth, identical volumes of $1 \mu \mathrm{l} 24 \mathrm{~h}$ old broth cultures were added into each flask. 
Antibiotic sensitivity: Twenty four-hour old broth cultures of ARB were spread on NA plates to attain lawn cultures, antibiotic discs placed and, plates incubated at room temperature for $24 \mathrm{hr}$. Inhibition zones around the discs were measured and, sensitivity of the isolates to a particular antibiotic was evaluated as per the chart provided by the manufacturer (Hi-Media, Mumbai).

Estimation of total arsenic: Experiments were set up to quantify the transformation of As by six ARB strains. Nutrient broth was amended with 10ppm As and, ARB isolates were inoculated individually. On all sampling days, $50 \mathrm{ml}$ broth was taken out from each flask for quantifying As. To differentiate between the cell-bound and biotransformed As, $25 \mathrm{ml}$ broth was passed through $0.22 \mu \mathrm{m}$ filters and As concentrations measured in duplicate from the filtrate by dividing it in to two parts. The other $25 \mathrm{ml}$ unfiltered broth was also divided and, As concentrations measured spectro-photometrically.

The As concentrations in the culture media were determined by the procedure of Koroleff (1976). In principle, as arsenate ion is isomorphic with phosphate ions, it forms similar yellow and blue molybdate complexes (Koroleff, 1976). Therefore, the photometric method based on the formation of arsenomolybdenum blue offer the greatest sensitivity for measuring arsenic. Following the method standardized for seawater we adopted the following steps to measure the arsenic in the culture media. Each filtrate was acidified with $0.5 \mathrm{ml} 9 \mathrm{~N}$ sulphuric acid. In to $50 \mathrm{ml}$ filtrates from freshwater isolates, $500 \mathrm{mg}$ of solid seawater mix (composition: $310 \mathrm{mg} \mathrm{NaCl}$ and $190 \mathrm{mg} \mathrm{MgSO}_{4} \cdot 7 \mathrm{H}_{2} \mathrm{O}$ ) was added as per Koroleff (1976). Only $\mathrm{MgSO}_{4}(190 \mathrm{mg})$ was added into $50 \mathrm{ml}$ filtrate of seawater nutrient broth. Into each of these filtrates, $2 \mathrm{ml}$ oxidation solution (composition: $5 \mathrm{~g}$ potassium peroxidisulphate $\left[\mathrm{K}_{2} \mathrm{~S}_{2} \mathrm{O}_{8}\right]$ in $100 \mathrm{ml}$ distilled water) was added and, the samples held under $15 \mathrm{PSI}$ pressure at $121^{\circ} \mathrm{C}$ for 30 minutes.

Following this, each filtrate was divided into two equal volumes of $26 \mathrm{ml}$ each. To one of the flasks (flask A), $0.30 \mathrm{ml}$ of iodate solution (composition: $0.15 \mathrm{~g} \mathrm{KIO}_{3}$ in $100 \mathrm{ml}$ distilled water) and $0.70 \mathrm{ml}$ of ascorbic acid (composition: $7 \mathrm{~g} \mathrm{C}_{6} \mathrm{H}_{8} \mathrm{O}_{6}$ in $100 \mathrm{ml}$ distilled water) was added. About 5 minutes later, 0.5 $\mathrm{ml}$ of freshly prepared mixed reagent (composition: $9 \mathrm{ml}$ ammonium heptamolybdate solution $\left[\left(\mathrm{NH}_{4}\right)_{6} \mathrm{Mo}_{7} \mathrm{O}_{24} \cdot 4 \mathrm{H}_{2} \mathrm{O}\right], 25 \mathrm{ml} 9 \mathrm{~N}$ sulphuric acid, $1 \mathrm{ml}$ potassium antimony tartrate solution $\left[\mathrm{K}(\mathrm{SbO}) \mathrm{C}_{6} \mathrm{H}_{4} \mathrm{O}_{6}\right]$ and $65 \mathrm{ml}$ distilled water) was added and held at room temperature for $90 \mathrm{~min}$. To the other flask (flask B), $0.5 \mathrm{ml}$ of ascorbic acid was added and kept aside for 75 minutes. Then, $0.25 \mathrm{ml}$ of sodium thiosulphate reagent (composition: $1.7 \mathrm{~g} \mathrm{Na}_{2} \mathrm{~S}_{2} \mathrm{O}_{3} .5 \mathrm{H}_{2} \mathrm{O}$ in $100 \mathrm{ml}$ distilled water and, add $50 \mathrm{mg}$ of $\mathrm{Na}_{2} \mathrm{CO}_{3}$ ) was added. After 15 minutes, $0.5 \mathrm{ml}$ of mixed reagent was added and allowed to stand for 5$7 \mathrm{~min}$. The ascorbic acid and mixed reagent being common, the iodate solution was added to flask A 
and, thiosulphate solution to flask B. All analyses were done in replicates of two sub-samples. The amount of arsenic calculated from the expression:

$\mu \mathrm{g}$ at As. $1^{-1}=F\left(A_{a}-A_{b}\right)$, where, $A_{a}$ is absorbance of solution in flask $A ; A_{b}$ is absorbance of solution in flask B and, F, calibration factor.

The above procedure was performed in full with distilled water for determining the reagent blank. Further, to obtain the calibration factor, a dilute standard solution (DSS) containing $0.4 \mu \mathrm{g}$ at As. $1^{-1}$ in distilled water was prepared. In brief, $100 \mathrm{ml} \mathrm{DSS}$ was made up to $200 \mathrm{ml}$ with synthetic seawater (composition: $6.4 \mathrm{~g} \mathrm{NaCl}, 2.8 \mathrm{~g} \mathrm{MgSO}_{4} .7 \mathrm{H}_{2} \mathrm{O}, 0.03 \mathrm{~g} \mathrm{NaHCO}_{3}$ in $200 \mathrm{ml}$ distilled water) and, $2 \mathrm{ml}$ of 9 N sulphuric acid added. Similarly, a blank solution (BS: equal volumes of synthetic seawater and distilled water) was also treated with $2 \mathrm{ml}$ of $9 \mathrm{~N}$ sulphuric acid. Two milliliters of oxidation solution was added into both DSS and BS and held under 15 PSI pressure at $121^{\circ} \mathrm{C}$ for 30 minutes. Following this the steps followed were the same as done for flask A above but for holding these flasks for 120 minutes before reading the absorbance using $10 \mathrm{~cm}$ column. The factor $\mathrm{F}$ was calculated from the expression,

$\mathrm{F}_{10 \mathrm{~cm}}=0.2 / \mathrm{A}_{\mathrm{st}}-\mathrm{A}_{\mathrm{b}}$ where, $\mathrm{A}_{\mathrm{st}}$ is mean absorbance of standards and, $\mathrm{A}_{\mathrm{b}}$ the mean of the blank.

\section{Results:}

Total viable counts (TVC) in water samples collected from oligohaline 'freshwater' location during all the three sampling months were more (2000 to $\left.9600 \mathrm{ml}^{-1}\right)$ than those from estuarine (1020-1600 $\mathrm{ml}^{-1}$ ) location (Table 1). In the overall, the percent of TVC from water samples capable of growth on nutrient agar amended with 15 ppm As was higher ( 20 to $36 \%$ ) than on NA with 25 ppm As ( $\sim 12$ to $18 \%$ ) or on NA with 50 ppm As ( $\sim 6$ to 13\%). All sediment samples had higher TVC compared to that of water. In general, samples collected during post-monsoon had higher counts than those collected during premonsoon or monsoon months. Similar to those observed for water samples, the TVC on NA amended with As decreased with increasing As concentration (Table 1). Upon noticing high counts on NA with 50ppm As, various higher concentrations of As (100, 200, 300 and 1000ppm) were added to NA and many isolates picked out and grown on these media. With increasing As concentrations the percent of isolates capable of growth decreased (Table 2).

The ARB strains were identified by an array of physiological and biochemical tests. Their morphological and biochemical characteristics are presented in Table 3. Of the nine environmental isolates characterized, FW1 and FW3 were found to belong to Enterobacteriaceae, FW2 and EW7 to 
Pseudomonas sp, FW4 to Corynebacterium sp, FS5 to Xanthomonas sp, EW6 to Acinetobacter sp, ES8 to Flavimonas sp and, ES9 to Micrococcus sp.

Growth pattern of all ARB strains is presented in figures 2a and 2b. From the increments of optical density, it can be summarized that the generation times were far longer in the presence of arsenic for all bacterial isolates tested. Many isolates exhibited prolonged lag phase in the presence of As. The growth was vigorous between 12 and $54 \mathrm{~h}$ in media without As. In the presence of As, the growth maxima were between 36 and 96 hours. The isolate FW4, a Corynebacterium sp, grew quite rapidly in the flask with As. Also, isolate ES8 did not differ much in its growth with and without As in the nutrient broth. Other isolates attained the exponential phase much later in the presence of arsenic.

Many of the ARB isolates were sensitive to most antibiotics except to penicillin, chloramphenical and oxytetracycline. Isolates identified as Enterobacteriaceae (FW1 and FW3), Pseudomonas sp (FW2), Corynebacterium sp (FW4), Acinetobacter sp (EW6) and Micrococcus sp (ES9) were sensitive to all antibiotics tested except penicillin G. Isolate identified as Flavimonas sp (ES8) was found to be sensitive to all tested antibiotics (Table 4).

Quantification of As biotransformation (Fig 3) was carried out for six ARB strains: FW1 and FW3 (Enterobacteriaceae), FW2 (Pseudomonas sp), ES9 (Micrococcus sp), FW4 (Corynebacterium sp) and EW6 (Acinetobacter sp). The percent As biotransformed from the growth medium was the highest by FW3 followed by FW 4 and EW6. The As biotransformed was as much as $45 \%$ by $24 \mathrm{~h}$ and close to $80 \%$ by $48 \mathrm{~h}$ by FW3. In deed, it biotransformed as much as $92 \%$ of the As in the growth medium by $120 \mathrm{hrs}$. The As concentrations were invariably lower in all the cell-free filtrates on all sampling days. While the cell-bound As built up marginally between day 2 and 4, it lowered substantially by $120 \mathrm{~h}$ in all six tested cultures (Fig 3).

\section{Discussion:}

Environmental effects of metal pollution are all-encompassing. It is evident from this study that the fractions of native bacteria growing in medium containing As is quite substantial. Ahmann et al. (1994) suggested that the microbial metabolism plays a greater, more direct role in arsenic cycling. As Newman et al. (1998) point out, some heterotrophic bacteria seem to use arsenite as an auxiliary source of energy, but others seem to oxidize arsenite to arsenate merely as a means of detoxification. Several isolates are reported to derive energy from As (III) oxidation and, perform oxidative As (III)-detoxification (Oremland and Stolz 2003). 
Many bacterial strains are reported to oxidize arsenite to arsenate (Osborne and Ehrlich 1976; Phillips and Taylor 1976; Gihring et al. 2001 and Langner et al. 2001). In our collection, most ARB isolates were gram negative except two non-motile isolates identified as Corynebacterium sp and Micrococcus sp that were gram positive. Although a fungus tolerating very high concentration $(\sim 1500$ ppm) of arsenic has also been isolated (Canovas et al. 2003), there are no such reports on bacteria. Thus, results from this study are useful to recognize the existence of quite a number of strains in various genera capable of tolerating and growing high concentrations. This observation brings to fore the need to evaluate the ecological significance of native flora capable of tolerating such high concentrations of As. Their percentages in the sampling sites being substantial, it is proposed that a large fraction of heterotrophic bacteria appears to be physiologically prepared to deal with current degree of pollution due to arsenic and other toxicants.

Growth of many isolates in the presence of $200 \mathrm{ppm}$ As implies that they do tolerate high concentrations of As. It is apparent therefore that the isolates we studied do possess the wherewithal to overcome the stress caused by high concentrations of As. This ability can be attributed to specific genes or plasmids (Silver and Phung 1996). The mechanism of resistance are generally efflux pumping and enzymatic detoxification converting a more toxic to a less toxic or less available metal-ion species (Silver et al. 2002). The prolonged lag phase in many strains we examined implies that the ARB undergoes physiological adjustments. As observed previously by Summers and Silver (1978) and Silver et al.(2002), in all the aerobic/facultative anaerobic heterotrophic cultures examined in this study, the inducible arsenic reductases might have enabled them to grow rapidly once adapted to the toxic milieu.

Bacterial resistance mechanisms to-and intracellular uptake of-trace metals from the seawater have been shown to follow different pathways. Many bacterial species have been shown to develop resistance to mercury and other heavy metals (Osborn and Ehrlich 1976; Silver and Phung 1996; Nies 1999; Ramaiah and De 2003; De and Ramaiah 2006; De et al. 2007 and 2008). In addition, microorganisms in the marine environment are thought to undergo selection pressures in the presence of toxic pollutants and, develop resistance. Thus resistance to As, and to various antibiotics, is possibly conferred chromosomally or by transposable elements in all the gram-negative bacteria examined in this study. Bacteria carrying As resistance also are resistant to many antibiotics as also seen in this study. However, elucidation of the relationship between antibiotic(s) and As resistance mechanisms in ARB needs further studies. 
Chemically, arsenite can be converted to less toxic, less mobile arsenate, which is less difficult to remove from the environment than arsenite. The recent reports described the broad diversity of microbes able either to reduce arsenate or to oxidize arsenite (Weeger et al. 1999). Studies quantifying the removal/transformation of As from the bacterial growth media are indeed lacking. From the observations of quite rapid biotransformation of As by all six different strains we tested, it is possible to suggest that only ARB, capable of such high tolerance for arsenic, would biotransform As in polluted estuarine environments. The bacterial oxidation of As (III) to As (V) represents a potential detoxification mechanism and, has applications in bioremediation because it generates less toxic and less mobile form of arsenate (Oremland et al. 2004). The bacterial strain Thiomonas sp. isolated from the Reigous Creek is shown by Casiot et al. (2003) to have the ability to oxidize As (III). Some strains in the genera Pseudomonas, Xanthomonas and Achromobacter are reported to oxidize arsenite to arsenate (Turner 1949). From this study, it is observed that many strains belonging to different genera are capable of growing on media with arsenite and also detoxify it.

Arsenite being highly toxic, it is considered as a primary pollutant in drinking water and therefore its efficient detoxification from natural waters is considered of great importance (Katsoyiannis and Zouboulis 2004). Environmental strains isolated from estuarine (brackish) waters are of practical interest

in arsenic detoxification (Rosen 2002). Since the isolates we examined are naturally occurring, they could be more environmentally acceptable and safe for detoxification of many metals. Such work may lead to practical techniques that can be adapted to freshwater systems and drinking water aquifers.

Acknowledgements: We thank Dr S R Shetye, Director NIO and, Dr A C Anil, Project Leader for Ballast water Control and Management Programme for facilities and encouragement. The Senior Research Fellowship to GSN by the CSIR, New Delhi is gratefully acknowledged. This is NIO contribution number. nnnn

\section{References:}

Ahmann D, Roberts AL, Krumholz LR, Morel FMM (1994) Microbe grows by reducing arsenic. Nature 371: 750

Anderson LCD, Bruland KW (1991) Biogeochemistry of arsenic in natural waters: The importance of methylated species. Environ Sci Technol 25: 420-427 
Canovas D, Cases I, Lorenzo de V (2003) Heavy metal tolerance and metal homeostasis in Pseudomonas putida as revealed by complete genome analysis. Environ Microbiol 5 (12): 1242-1256

Casiot C, Morin G, Juillot F, Bruneel O, Personne J-C, Leblanc M, Duquesne K, Bonnefoy V, ElbazPoulichet F (2003) Bacterial immobilization and oxidation of arsenic in acid mine drainage (Carnoules creek, France).Water Res 37: 2929-2936

Chen TH, Gross JA, Karasov WH (2009) Chronic exposure to pentavalent arsenic of larval leopard frogs (Rana pipiens): bioaccumulation and reduced swimming performance. Ecotoxicology PubMed ID 19396542

De J, Sarkar A, Ramaiah N (2006) Bioremediation of toxic substances by mercury resistant marine bacteria. Ecotoxicology 15(4): 385-9

De J, Ramaiah N (2006) Occurrence of large fractions of mercury-resistant bacteria in the Bay of Bengal. Current Science 91 (3): 368-372

De J, Ramaiah N, Bhosle N B, Garg A, Vardanyan L, Nagle V L, Fukami K (2007) Potential of Mercury-resistant Marine Bacteria for Detoxification of Chemicals of Environmental Concern. Microbes and Environments 22 (4): 336-345

De J, Ramaiah N, Vardanyan L (2008) Detoxification of Toxic Heavy Metals by Marine Bacteria Highly Resistant to Mercury. Marine Biotechnol 10 (4): 471-477

Erhlich HL (1997) Microbes and metals. Appl Microbiol Biotechnol 48: 687-692

Gihring TM, Druschel GK, Mccleskey RB, Hamers RJ, Banfield JF (2001) Rapid arsenite oxidation by Thermus aquaticus and Thermus thermophilus: field and laboratory investigations. Environ Sci Technol 35: 3857-3862

Holt JG, Krieg NR, Sneath PHA, Staley JT, Williams ST (2000) Bergy's manual of determinative bacteriology. ninth edition. Lippincott Williams and Wilkins, USA

Katsoyiannis I, Zouboulis A (2004) Application of biological processes for the removal of arsenic from groundwaters. Water Res 38: 17-26

Koroleff F (1976) Determination of arsenic. In: Grasshoff K. (ed.), Methods of seawater analysis. Verlag Chemie, Weinheim, New York 158-167

Langner HW, Jackson CR, Mcdermott TR, Inskeep WP (2001) Rapid oxidation of arsenite in a hot spring ecosystem, Yellowstone National Park. Environ Sci Technol 35: 3302-3309

Lee J-U, Lee S-W, Kim K-W, Yoon C-H (2005) The effects of different carbon sources on microbial mediation of arsenic in arsenic-contaminated sediment. Environ Geochem Health 27: 159-168 
Liu J, Li Y, Zhang B, Cao J, Cao Z, Domagalski J (2009) Ecological risk of heavy metals in sediments of the Luan River source water. Ecotoxicology PubMed ID 19499329

Maher W, Barwick M (2003) Biotransference and biomagnification of selenium copper, cadmium, zinc, arsenic and lead in a temperate seagrass ecosystem from

Lake Macquarie Estuary, NSW, Australia. Mar Environ Res 56: 471-502

Macy JM, Santini JM, Pauling BV, O’Neill AH, Sly LI (2000) Two new arsenate/sulfate-reducing bacteria: mechanisms of arsenate reduction. Arch Microbiol 173: 49-57

Mukhopadhyay R, Rosen BP, Phung LT, Silver S (2002) Microbial arsenic: from geocycles to genes and enzymes. FEMS Microbiol Rev 26: 311-325

Nair M, Joseph T, Balachandran KK, Nair KKC, Paimpillii JS (2003) Arsenic enrichment in estuarine sediments-impact of iron and manganese mining. Fate of arsenic in the environment. eds. by: Ahmed, MF, Ali MA, Adeel Z (Int. Symp. on Fate of Arsenic in the Environment; Dhaka; Bangladesh; Feb 2003). International Training Network (ITN); Dhaka; Bangladesh Pp.57-67

Neff JM (1997) Ecotoxicology of arsenic in the marine environment (Review). Environ Toxicol Chem 16:917-927

Newman DK, Ahmann D, Morel FMM (1998) A brief review of microbial arsenate respiration. Geomicrobiol J 15: 225-268

Nickson R, McArthur J, Burgess W, Ahmed KM, Ravenscroft P, Rahman M (1998) Arsenic poisoning of Bangladesh groundwater. Nature 395: 338

Nies DH (1999) Microbial heavy metal resistance. Appl Microbiol Biotechnol 51: 730-750

Oremland RS, Stolz JF (2003) The ecology of arsenic. Science 300: 939-944

Oremland RS, Stolz JF, Hollibaugh JT (2004) The microbial arsenic cycle in Mono Lake, California. FEMS Microbiol Eco 48: 15-27

Osborne FH, Ehrlich HE (1976) Oxidation of arsenite by a soil isolate of Alcaligenes. J Appl Bacteriol 41: 295-305

Pacyna JM, Pacyna EG (2001) An assessment of global and regional emissions of trace metals to the atmosphere from anthropogenic sources worldwide. Environ Rev 9: 269-298

Phillips SE, Taylor ML (1976) Oxidation of arsenite to arsenate by Alcaligenes faecalis. Appl Environ Microbiol 32: 392-399 
Ramaiah N, De J (2003) Unusual rise in mercury-resistant bacteria in Coastal Environments. Microbial Ecol 45: 444-454

Rosen BP (2002) Biochemistry of arsenic detoxification. FEBS Letters 529: 86-92

Sanders J G, Windom HL (1980) The uptake and reduction of arsenic species by marine algae. Est Coast Mar Sci 10: $555-567$

Sawkar K, Pvethamony Babu MT, Dias C, Mesquita A, Fernandes B, Moses S, Padmavati M, Naik S (2003) Measuring, modeling and grading the health of water bodies. Coastal tourism, environment, and sustainable local development 179-210

Silver S, Phung LT (1996) Bacterial heavy metal resistance: New Surprise. Annu Rev Microbiol 50: 753-789

Silver S, Phung LT, Rosen BP (2002) Arsenic metabolism: resistance, reduction and oxidation. In W.T. Frankenberger, Jr. (ed.), Environmental chemistry of arsenic. Marcel Dekker, Inc., New York, N.Y. Pp.247272

Summers AO, Silver S (1978) Microbial Transformations of Metals. Annu Review Microbiol 32: 637-672

Turner AW (1949) Bacterial oxidation of arsenite. Nature 164: 76-77

Weeger W, Lievremont D, Perret M, Lagarde F, Hubert JC, Leroy M, Lett MC (1999) Oxidation of arsenite to arsenate by a bacterium isolated from an aquatic environment. Biometals 12: 141-149

Williams JW, Silver S (1984) Bacterial resistance and detoxification of heavy metals. Enz Microb Technol 6: 530-537

Woolson EA, Axley JH, Kearney PC (1973) The chemistry and phytotoxicity of arsenic in soils: II. Effects of time and phosphorus. Soil Sci Soc Am Proc 37: 254-259 


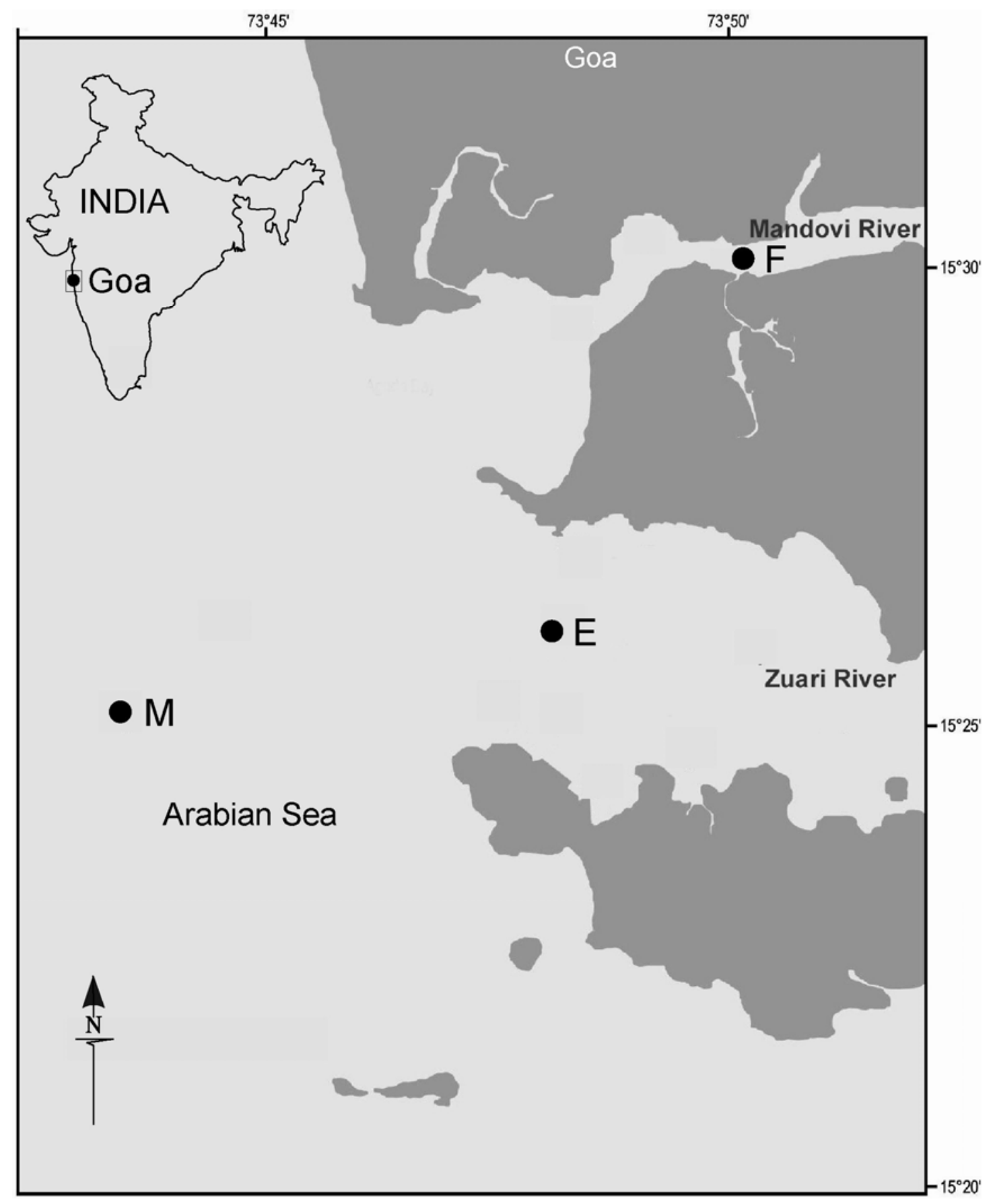

Fig 1 Sampling Locations: $\mathrm{M}$ is a marine, $\mathrm{F}$ a 'freshwater' and $\mathrm{E}$, an estuarine location

Fig 1 Nagvenkar and Ramaiah 

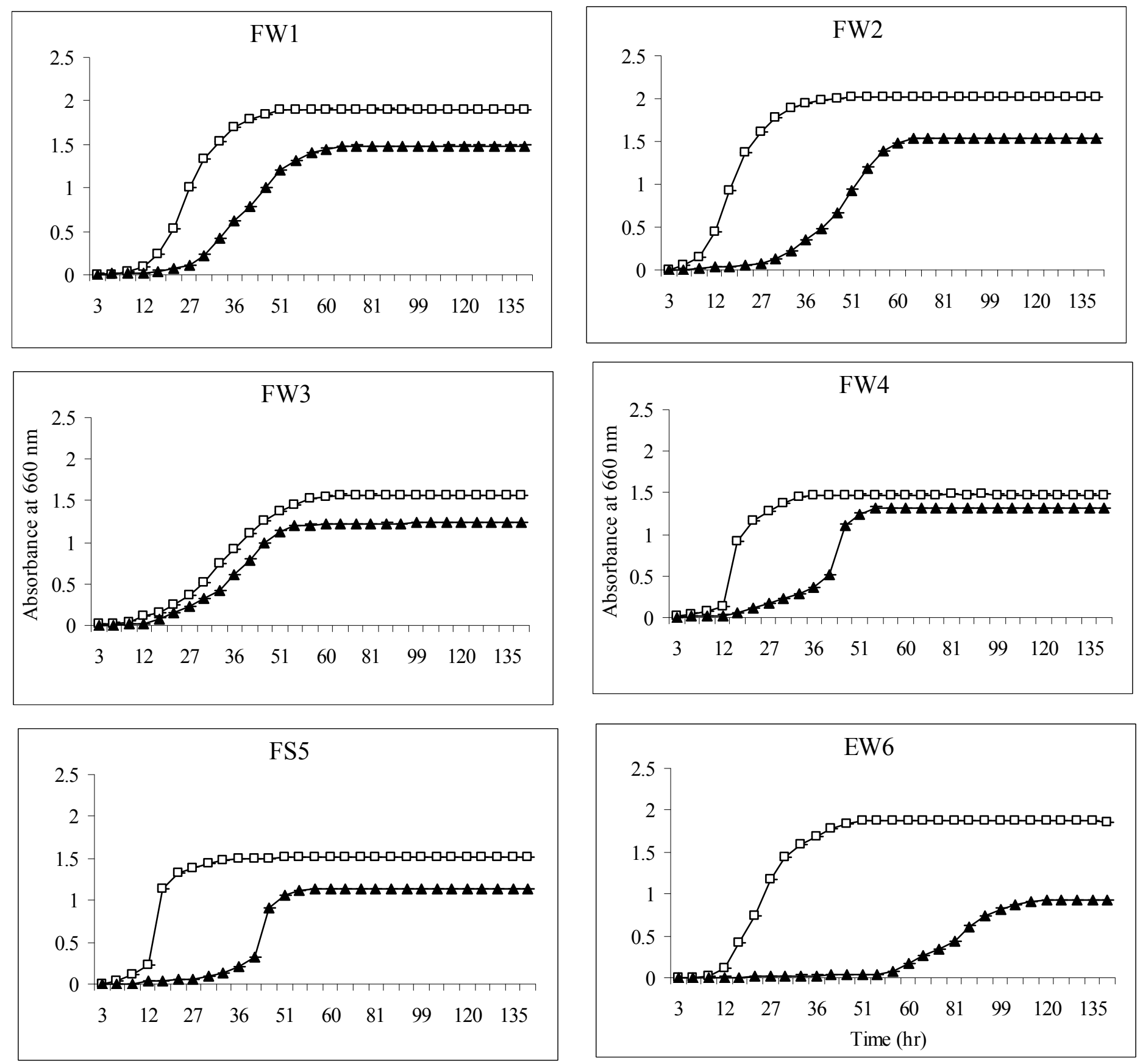


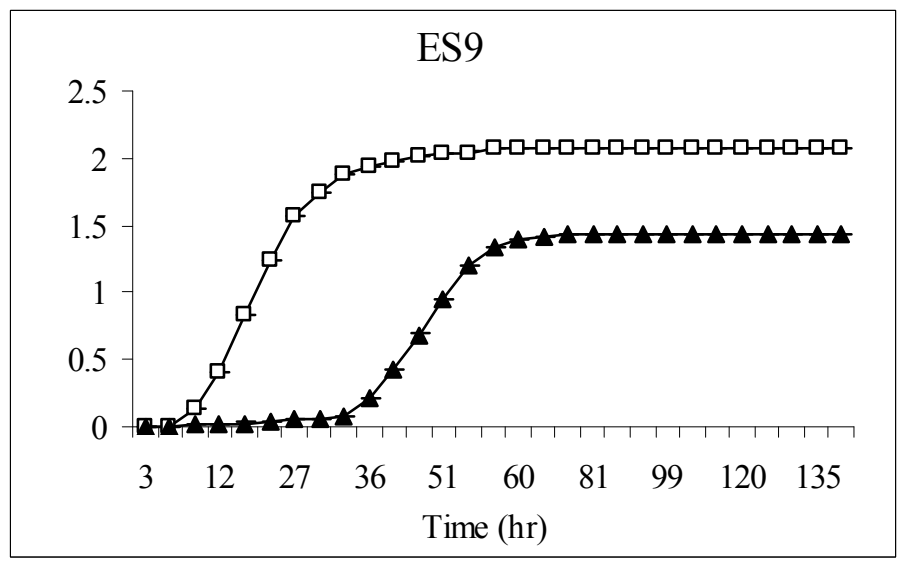

Fig 2a Growth $\left(\mathrm{OD}_{600}\right)$ of different isolates in nutrient broth (NB) without arsenite (open squares) and in NB amended with 200ppm arsenite (triangles). Isolates FW1 and FW3 belong to Enterobacteriaceae; FW2 to Pseudomonas sp; FW4 to Corynebacterium sp; FS5 to Xanthomonas sp, EW6 to Acinetobacter sp and, ES9 to Micrococcus sp.

Fig 2a Nagvenkar and Ramaiah

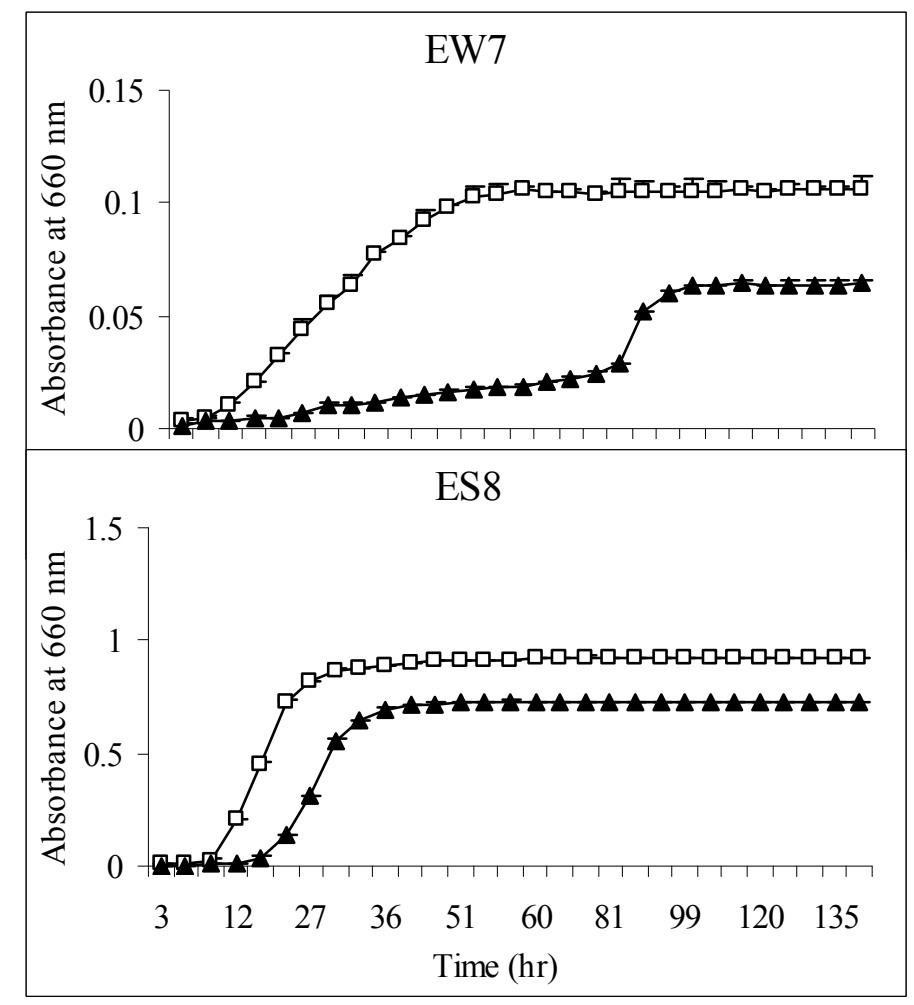

Fig 2b Growth $\left(\mathrm{OD}_{600}\right)$ of two strains of estuarine bacteria, EW7 (Pseudomonas sp) and ES8 (Flavimonas sp) in nutrient broth (NB) without arsenite (open squares) and in NB amended with 200ppm arsenite (triangles)

Fig 2b Nagvenkar and Ramaiah 

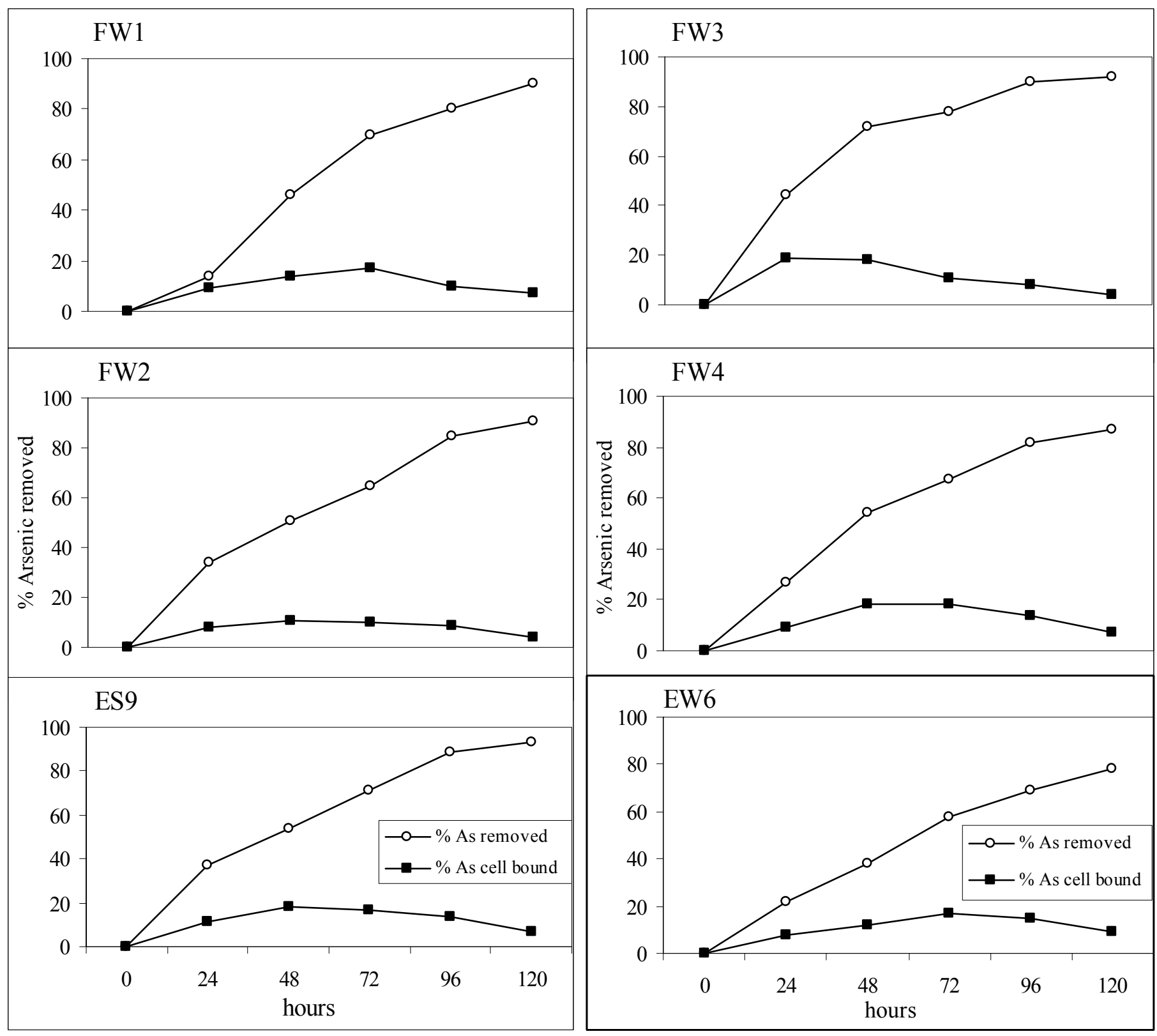

Fig 3 Percent of arsenic biotransformed from the growth medium by bacterial isolates FW1 and FW3 (Enterobacteriaceae); FW2 (Pseudomonas sp); ES9 (Micrococcus sp); FW4 (Corynebacterium sp) and EW6 (Acinetobacter sp). The arsenite concentration was almost unaltered in $10 \mathrm{ppm}$ amended, uninoculated nutrient broth and seawater blanks throughout the experimental period

Fig 3 Nagvenkar and Ramaiah 
Table 1. Number of colony forming units (CFU) of bacteria growing in different concentrations of arsenite $\left(\mathrm{As}_{2} \mathrm{O}_{3}\right)$

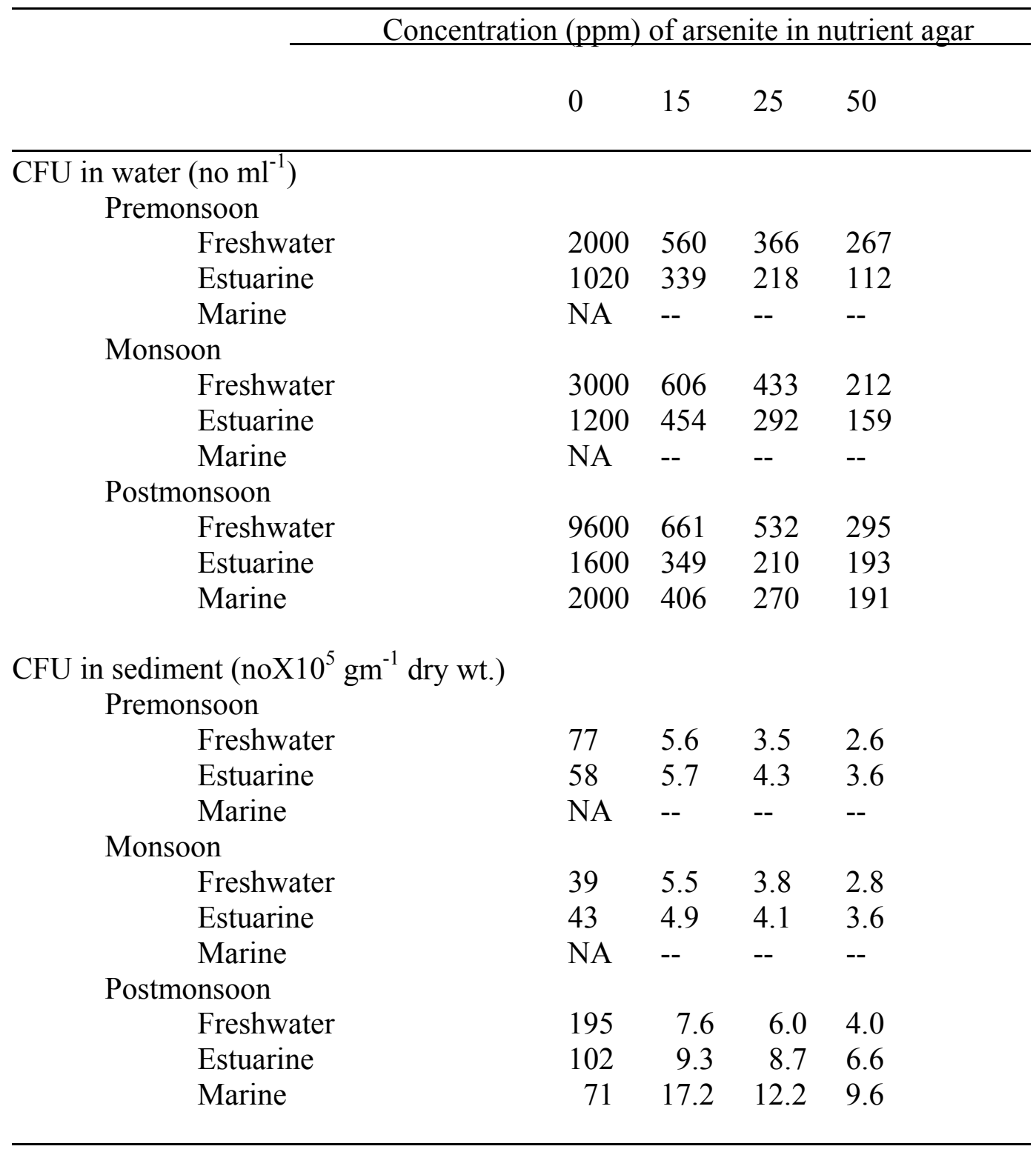


Table 2. Percent of arsenite resistant bacteria capable of growth in increasing concentration of arsenic

\begin{tabular}{lcccc}
\hline $\begin{array}{l}\text { No of isolates } \\
\text { tested }\end{array}$ & \multicolumn{4}{c}{ Concentration of arsenic in Nutrient agar } \\
\hline & $100 \mathrm{ppm}$ & $200 \mathrm{ppm}$ & $300 \mathrm{ppm}$ & $1000 \mathrm{ppm}$ \\
\cline { 2 - 5 } & $48(100 \%)$ & $46(96 \%)$ & $46(96 \%)$ & $10(21 \%)$ \\
Freshwater (48) & $52(100 \%)$ & $44(85 \%)$ & $44(85 \%)$ & $16(31 \%)$ \\
Estuarine (52) & $56(100 \%)$ & $32(57 \%)$ & $32(57 \%)$ & $12(21 \%)$ \\
\hline
\end{tabular}


Table 3. Morphological and biochemical characteristics of bacterial isolates capable of growth in medium with $1000 \mathrm{ppm}$ arsenite

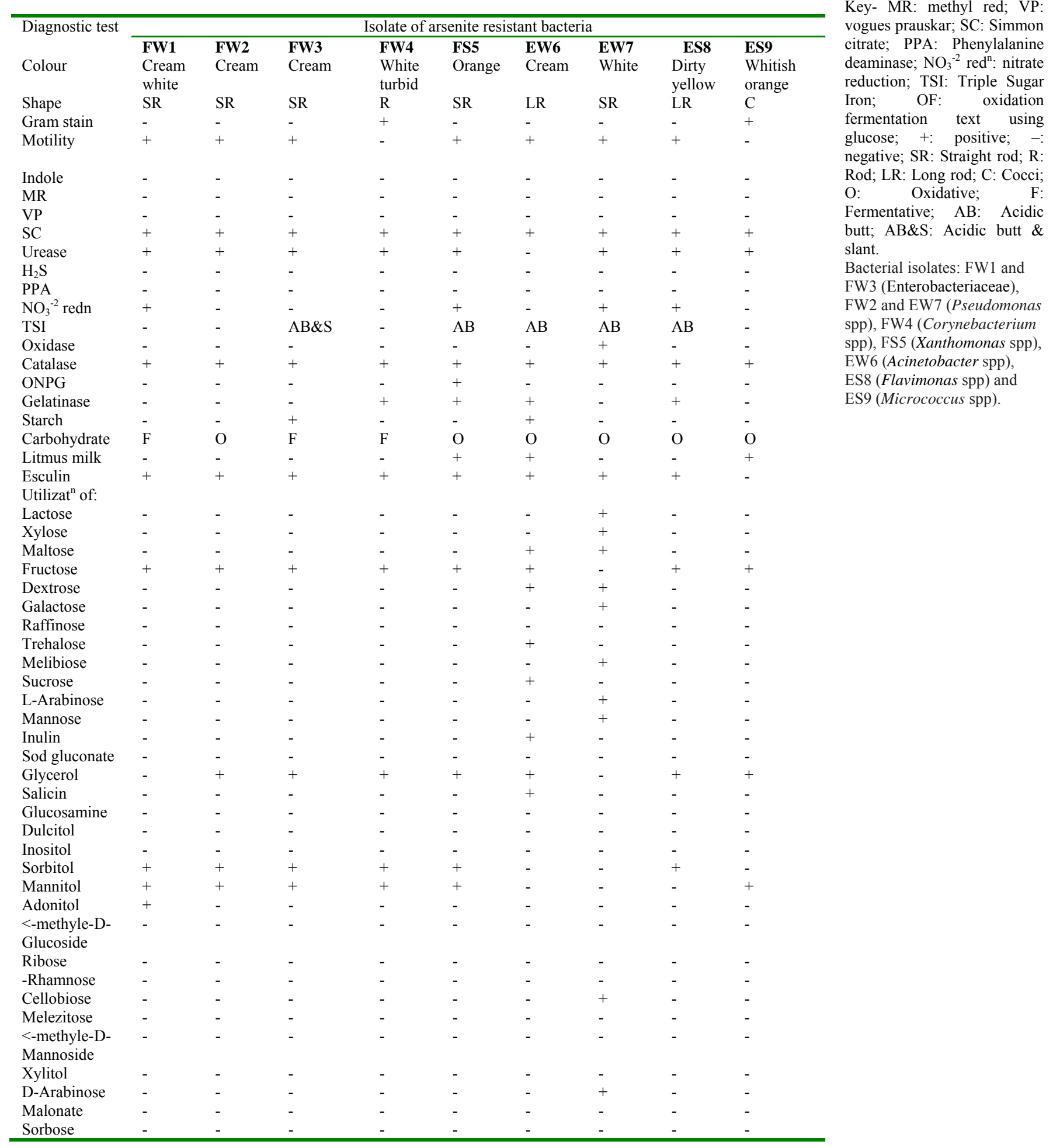


Table 4. Response of Arsenite resistant bacteria to antibiotics measured in terms of inhibition zone in $\mathrm{mm}$ diameter

\begin{tabular}{|c|c|c|c|c|c|c|c|c|c|c|c|}
\hline \multirow{3}{*}{$\begin{array}{l}\text { Antibiotics } \\
\text { tested }\end{array}$} & \multirow{3}{*}{$\begin{array}{c}\text { Tested } \\
\text { conc } \\
(\mu \mathrm{g} / \text { disc })\end{array}$} & \multirow{3}{*}{$\begin{array}{c}\text { Sensitivity } \\
\text { limit } \\
(\mathrm{mm}) \\
\end{array}$} & \multicolumn{9}{|c|}{ Isolates of arsenite resistant bacteria } \\
\hline & & & FW1 & FW2 & FW3 & FW4 & FS5 & EW6 & EW7 & ES8 & ES9 \\
\hline & & & \multicolumn{9}{|c|}{ Zone of inhibition diameter in $\mathrm{mm}$} \\
\hline Penicillin $-\mathrm{G}$ & $10 \mathrm{U}$ & 29 & $19(\mathrm{R})$ & $15(\mathrm{R})$ & $12(\mathrm{R})$ & $20(\mathrm{R})$ & $37(\mathrm{~S})$ & $25(\mathrm{R})$ & $\mathrm{NZ}$ & $37(\mathrm{~S})$ & $27(\mathrm{R})$ \\
\hline Streptomycin & 25 & 15 & $26(\mathrm{~S})$ & $23(\mathrm{~S})$ & $27(\mathrm{~S})$ & $22(\mathrm{~S})$ & $\mathrm{NZ}$ & $19(\mathrm{~S})$ & $\mathrm{NZ}$ & $25(\mathrm{~S})$ & $15(\mathrm{~S})$ \\
\hline Tetracycline & 30 & 19 & $20(\mathrm{I})$ & $30(\mathrm{~S})$ & $21(\mathrm{I})$ & $29(\mathrm{~S})$ & $22(\mathrm{I})$ & $30(\mathrm{~S})$ & $38(\mathrm{~S})$ & $30(\mathrm{~S})$ & $25(\mathrm{~S})$ \\
\hline Chloramphenicol & 30 & 18 & $21(\mathrm{~S})$ & $21(\mathrm{~S})$ & 19 (I) & 20 (I) & $17(\mathrm{R})$ & $21(\mathrm{~S})$ & $\mathrm{NZ}$ & $30(\mathrm{~S})$ & $24(\mathrm{~S})$ \\
\hline Kanamycin & 30 & 18 & $15(\mathrm{I})$ & $19(\mathrm{~S})$ & 15 (I) & $16(\mathrm{I})$ & $14(\mathrm{I})$ & $18(\mathrm{~S})$ & $24(\mathrm{~S})$ & $25(\mathrm{~S})$ & $22(\mathrm{~S})$ \\
\hline Gentamycin & 30 & 15 & $14(\mathrm{I})$ & $27(S)$ & $24(\mathrm{~S})$ & $28(\mathrm{~S})$ & $25(\mathrm{~S})$ & $38(\mathrm{~S})$ & $35(\mathrm{~S})$ & $21(\mathrm{~S})$ & $15(\mathrm{~S})$ \\
\hline Oxytetracycline & 30 & 19 & $24(\mathrm{~S})$ & $26(S)$ & $23(\mathrm{~S})$ & $21(\mathrm{~S})$ & $15(\mathrm{R})$ & $21(\mathrm{~S})$ & $29(\mathrm{~S})$ & $31(\mathrm{~S})$ & $20(\mathrm{~S})$ \\
\hline Neomycin & 30 & 17 & $18(\mathrm{~S})$ & $18(\mathrm{~S})$ & $17(\mathrm{~S})$ & $21(\mathrm{~S})$ & $\mathrm{NZ}$ & $25(\mathrm{~S})$ & $\mathrm{NZ}$ & $29(\mathrm{~S})$ & $20(\mathrm{~S})$ \\
\hline
\end{tabular}

Key: R- Resistant; S-Sensitive; I-Intermediate; NZ- no zone of inhibition Bacterial isolates: FW1 and FW3 (Enterobacteriaceae), FW2 and EW7 (Pseudomonas sp), FW4 (Corynebacterium sp), FS5 (Xanthomonas sp), EW6 (Acinetobacter sp), ES8 (Flavimonas sp) and ES9 (Micrococcus sp). 